\title{
Synthesis and DFT characterisation of 2-arylamino-1,4- benzoquinone derivatives as potential electron transfer mediators
}

\author{
Edita Voitechovič ${ }^{1,2}$, \\ Regina Jančienè ${ }^{1}$, \\ Gema Mikulskiené ${ }^{1}$, \\ Aušra Vektariené $\dot{e}^{3}$ \\ Gytis Vektaris ${ }^{3}$, \\ Julija Razumienè ${ }^{1}$ \\ ${ }^{1}$ Institute of Biochemistry, \\ Life Sciences Center, \\ Vilnius University, \\ 7 Sauletekio Avenue, \\ 10257 Vilnius, Lithuania \\ ${ }^{2}$ Department of Nanoengineering, \\ Center for Physical Sciences and Technology, \\ 231 Savanoriu Street, \\ 02300 Vilnius, Lithuania \\ ${ }^{3}$ Institute of Theoretical Physics \\ and Astronomy, \\ Vilnius University, \\ 3 Sauletekio Avenue, \\ 10222 Vilnius, Lithuania
}

\begin{abstract}
A series of new potential electron transfer mediators, 2-substituted 1,4-benzoquinone derivatives bearing an arylamino group with various substituents in $o$-, $m$ - and $p$-positions of an aromatic ring were synthesised by adding a solution of aniline derivatives in aqueous acetic acid to an aqueous solution of 1,4-benzoquinone. The structure and properties of synthesised compounds were investigated by NMR spectroscopy methods in detail. The redox ability of 2-arylamino-1,4-benzoquinone derivatives has been estimated by calculations of quantum chemical structureactivity relationship (QSAR) descriptors within the framework of density functional theory.
\end{abstract}

Keywords: 1,4-benzoquinone, aromatic amine, 2-arylamino-1,4-benzoquinone, NMR spectroscopy, quantum chemical structure-activity relationship (QSAR) descriptors, electron transfer mediator

\section{INTRODUCTION}

In the context of 'life quality improvement' in different fields, such as medicine, food, environmental or safety control, the development of new technologies operating on a base of bioelectrocatalysis is applied more and more. Employment

\footnotetext{
* Corresponding author. Email: edita.voitechovic@ftmc.lt; regina.janciene@bchi.vu.lt
}

of enzymes as biocatalysts in these processes offers the benefits for sustainable green methodologies concerning biosensorics, bioconversion reactors or fuel cells. The bioelectrocatalytic system combines a biological element and a suitable transducer converting the response from interaction with the target analyte into a quantifiable signal [1]. However, an effective electron transfer in bioelectrocatalysis requires the presence of an 
intermediary compound, the so-called mediator. The mediator shuttles redox equivalents between a bio-element (enzyme) and a transducer (electrode), and this supplementary step usually results in an increased effectivity of the system in terms of selectivity and sensitivity. In fact, a good mediator must fulfil a number of requisites such as: it should be absorbed on the surface of the electrode, be retained active on it, react rapidly with the reduced enzyme, be stable in the reduced and oxidised forms and, finally, be non-toxic [2]. In this context, a number of electron acceptors and complexes as well as various methodologies involved in the mediated systems have been created and still in focus nowadays [3]. Due to fast and reversible redox-reactions quinone derivatives have attracted a special attention as potential mediators. Recently, the influence of electron donating substituents on the electrochemical oxidation behaviour of methyl substituted 1,4-benzoquinone derivatives was discussed with the help of quantum chemical calculations [4]. Also, aminated quinoidal compounds have been examined as redox mediators applicable for bioelectrocatalytic systems using two types of pyrroloquinoline quinone-dependent alcohol dehydrogenases as well as the determinated molecular characters by $a b$ initio quantum chemical calculation have been suggested as a useful instrument for predicting of potential mediators in the biosensors based on different oxidoreductases [5]. Thus, in our opinion, 2-arylamino-substituted 1,4-benzoquinone derivatives having two oxygen atoms of different activity and, therefore, modified redox properties compared to quinone are of interest as potential electron transfer mediators.

The aim of our work was to synthesise a series of 2-substituted 1,4-benzoquinone derivatives bearing an arylamino group with various substituents in $o^{-}, m$ - and $p$-positions of an aromatic ring, and a detail study of the structure and properties of the obtained products using NMR spectroscopy. According to the literature, 2-arylamino-1,4benzoquinones are readily formed as the main product by treatment of $p$-benzoquinone with aromatic amines in the aqueous medium [6-9]. However, the authors give different reaction conditions and melting characteristics for the same compounds. For example, the melting point for 2-phenylamino-1,4-benzoquinone is indicated as $117-118^{\circ} \mathrm{C}[10], 131-133^{\circ} \mathrm{C}[9], 139-140^{\circ} \mathrm{C}$ [1] and, meanwhile, the reaction temperature ranges from cooling at $0^{\circ} \mathrm{C}[7]$ to heating at $50-70^{\circ} \mathrm{C}[9]$ for a similar process time. On the other hand, some researches note that this reaction usually gives a mixture of mono- and dianilino-1,4-benzoquinones [7, 11, 12]. Only by a suitable selection of the temperature, time and solvent the mono- or disubstituted derivatives of benzoquinone and primary aromatic amines can be synthesised [7]. In order to avoid the formation of disubstituted derivatives the reactions were carried out at low temperatures in dilute solutions [11]. Therefore in this work we thoroughly investigated a conjugate addition of aromatic amines: $\mathrm{N}$-methylaniline, $m$ nitro-, $p$ - and $o$-methoxy- or fluorosubstituted anilines to 1,4-benzoquinone (BQ) and established the optimal reaction conditions for the synthesis of sufficiently pure target products. We present a detailed description of the synthesis, purification procedures and structure evaluation of the obtained 2-arylamino-1,4-benzoquinones.

In a view of our special interest to synthesise new promising and potential electron transfer mediators in the range of 2-arylamino-1,4-benzoquinone derivatives, we have made an attempt to estimate their electron transfer (redox) ability by calculations of quantum chemical structureactivity relationship (QSAR) descriptors. The obtained results have been compared with those of the well-known standard electron transfer mediator BQ. The use of QSAR descriptors is of great importance for screening a series of compounds in order to select structures with the desired molecular properties, including those not yet synthesised [13-16]. The general idea of QSAR descriptors has been widely presented in the past [17]. It means the rules to transform searches of compounds with definite, desirable molecular properties into a computationally quantified mathematical form. The correlations between the structure and activity properties have been detected for important findings in bioelectrochemistry [1820]. So, in this way, with the help of calculated QSAR descriptors, it becomes possible to examine the newly synthesised 2-arylamino-1,4-benzoquinone molecular structures, then find a relationship between molecular structures and desired electron transfer properties. This hereafter enables one to select the most promising electron transfer 
compounds for bioelectrocatalytic systems and to synthesise them in the laboratory. Therefore, in this work we have made an attempt to define how the newly synthesised arylamino-1,4-benzoquinones benefit the characteristics of effective electron transfer mediators by calculation of their electron accepting and donating ability expressed by appropriate QSAR descriptor characters. A further experimental evaluation of the synthesised compounds in terms of electron transfer mediators in bioelectrocatalytic systems are in our closest plans.

\section{EXPERIMENTAL}

\section{Chemistry}

Materials. 3-Nitroaniline, N-methylaniline, 2-methoxyaniline and 4-methoxyaniline were obtained from Sigma Aldrich (Germany). 1,4-Benzoquinone, 2-fluoroaniline and 4-fluoroaniline were supplied by Alfa Aesar (Germany). Chloroform was from AppliChem (Germany). Bi-distilled water was made employing a local custom made distiller (Institute of Biochemistry, Life Sciences Center, Vilnius University, Lithuania).

General methods. Melting points were determined in open capillaries on a MEL-TEMP 1202D apparatus and are uncorrected. ${ }^{1} \mathrm{H}$ and ${ }^{13} \mathrm{C}$ NMR spectra were recorded on a Varian Unity Inova 300 operating in the Fourier transform mode and Bruker Ascend $^{\text {tm }} 400$ at $302 \mathrm{~K}$. Chemical shifts are given in $\delta$ units (ppm), relative to the TMS as the internal standard and referenced to the centre of the deuterated solvent signal: $\mathrm{CDCl}_{3}(7.26$, $77.0 \mathrm{ppm})$ and DMSO- $\mathrm{d}_{6}(2.5,39.5 \mathrm{ppm})$ for ${ }^{1} \mathrm{H}$ and ${ }^{13} \mathrm{C}$ spectra, respectively. ${ }^{19} \mathrm{~F}$ spectra are given relative to $\mathrm{CFCl}_{3}$, and referenced to $\mathrm{CF}_{3} \mathrm{COOH}$ $(-76.5 \mathrm{ppm})$ as the internal standard. The values of chemical shifts are expressed in ppm and coupling constants $(J)$ in $\mathrm{Hz}$. The spectral data of the third composed aromatic ring of compound $4 \mathbf{e}$ are marked in italic. Elemental analyses (C, $\mathrm{H}, \mathrm{N}$ ) were performed on an Elemental Analyser CE-440. The reactions were controlled by the TLC method and performed on a Merck precoated silica gel aluminum roll $\left(60 \mathrm{~F}_{254}\right)$ with chloroformethyl acetate $(v / v, 14: 7)$ as the eluent. Dry column vacuum chromatography was performed with silica gel 60 (0.015-0.040 mm, Merck).

General procedure for the synthesis of 1,4-benzoquinone derivatives $2 a-f, 3 b$, e and 4e. BQ (10 or $20 \mathrm{mmol}$, see Table 1) was dissolved in hot distilled water $\left(60^{\circ} \mathrm{C}\right)$, and the solution was clarified by filtration. The filtrate was cooled and a solution of the appropriate aniline $\mathbf{1 a}-\mathbf{f}$ $(10 \mathrm{mmol})$ was added to it. The solution of aniline 1a-f was prepared by adding $10 \mathrm{mmol}$ of these compounds into water $(50 \mathrm{ml})$ and then adding acetic acid under stirring until all amine dissolved. The resulting mixture was stirred at the required temperature for 15-20 min (see Table 1). The formed dark crystals were filtered off, washed with water and dried under reduced pressure.

2-(3-Nitrophenylamino)cyclohexa-2,5-dieno-1,4-dione (2a). Dark violet crystals, m. p. $250-260^{\circ} \mathrm{C}$ (lit. m. p. $290-300^{\circ} \mathrm{C}$ [21]). ${ }^{1} \mathrm{H}$ NMR (300 MHz, DMSO-d $)$ ): $\delta=6.08$ (br. d., $J=1.9 \mathrm{~Hz}$, $1 \mathrm{H}, 3-\mathrm{CH}$ ), 6.75 (br. d., $J=1.8 \mathrm{~Hz}, J=10.0 \mathrm{~Hz}, 1 \mathrm{H}$, 5-CH), 6.87 (br. d., $J=10.0 \mathrm{~Hz}, 1 \mathrm{H}, 6-\mathrm{CH}$ ), 7.67 (br. t, $J=7.7 \mathrm{~Hz}, 1 \mathrm{H}, 5^{\prime}-\mathrm{CH}$ ), 7.81 (br. d., $J=7.4 \mathrm{~Hz}$, $1 \mathrm{H}, 6^{\prime}-\mathrm{CH}$ ), 7.98 (br. d., $J=7.7 \mathrm{~Hz}, 1 \mathrm{H}, 4^{\prime}-\mathrm{CH}$ ), 8.18 (br. s., $1 \mathrm{H}, 2^{\prime}-\mathrm{CH}$ ), 9.30 (br. s., $\left.1 \mathrm{H}, \mathrm{NH}\right) .{ }^{13} \mathrm{C}$ NMR $(75 \mathrm{MHz}$, DMSO-d $)$ ): $\delta=101.38(\mathrm{C}-3), 117.14$ (C-22), 118.92 (C-42), 8.73 (C-5'), $130.61\left(\mathrm{C}-6^{\prime}\right)$, 133.52 (C-5), 138.46 (C-6), 139.68 (C-1'), 143.63 (C-2), 148.32 (C-32), 183.34 (C-4), 186.36 (C-1).

2-[Methyl(phenyl)amino]cyclohexa-2,5-dieno-1,4-dione (2b). Dark brown crystals, m. p. $120-130^{\circ} \mathrm{C}$ (lit. m. p. $139-140^{\circ} \mathrm{C}$ [22], lit. m. p. $\left.125-130^{\circ} \mathrm{C}[6]\right) .{ }^{1} \mathrm{H}$ NMR (300 $\left.\mathrm{MHz}, \mathrm{CDCl}_{3}\right)$ : $\delta=3.33\left(\mathrm{~s}, 3 \mathrm{H}, \mathrm{N}-\mathrm{CH}_{3}\right), 5.84(\mathrm{~d}, J=2.3 \mathrm{~Hz}, 1 \mathrm{H}$, $3-\mathrm{CH}), 6.49(\mathrm{~d}, J=10.0 \mathrm{~Hz}, 1 \mathrm{H}, 6-\mathrm{CH}), 6.63$ $(\mathrm{dd}, J=2.3 \mathrm{~Hz}, J=10.0 \mathrm{~Hz}, 1 \mathrm{H}, 5-\mathrm{CH}), 7.07$ (d, $\left.J=7.4 \mathrm{~Hz}, 2 \mathrm{H}, 2^{\prime}, 6^{\prime}-\mathrm{CH}\right), 7.25(\mathrm{t}, J=7.4 \mathrm{~Hz}$, $\left.1 \mathrm{H}, 4^{\prime}-\mathrm{CH}\right), 7.37$ (t, $\left.J=7.4 \mathrm{~Hz}, 2 \mathrm{H}, 3^{\prime}, 5^{\prime}-\mathrm{CH}\right)$. ${ }^{13} \mathrm{C}$ NMR $\left(75 \mathrm{MHz}, \mathrm{CDCl}_{3}\right): \delta=42.84\left(\mathrm{NCH}_{3}\right)$, $109.13(\mathrm{C}-3), 5.22\left(\mathrm{C}-2^{\prime}, 6^{\prime}\right), 6.45\left(\mathrm{C}-4^{\prime}\right), 9.62(\mathrm{C}-$ $\left.3^{\prime}, 5^{\prime}\right), 134.67$ (C-5), 137.35 (C-6), 147.37 (C-1'), 150.10 (C-2), 183.86 (C-4), 186.18 (C-1).

2,5-bis [Methyl (phenyl) a mino] cyclohexa-2,5-dieno-1,4-dione (3b). Brown crystals, m. p. $200-210^{\circ} \mathrm{C}$ (lit. m. p. $205^{\circ} \mathrm{C}$ [ 6 ). ${ }^{1} \mathrm{H}$ NMR $\left(300 \mathrm{MHz}, \mathrm{CDCl}_{3}\right): \delta=3.39\left(\mathrm{~s}, 6 \mathrm{H}, \mathrm{N}-\mathrm{CH}_{3}\right)$, $5.55(\mathrm{~s}, 2 \mathrm{H}, 3,6-\mathrm{CH}), 7.13(\mathrm{~d}, J=7.5 \mathrm{~Hz}, 4 \mathrm{H}$, $\left.2^{\prime}, 6^{\prime}-\mathrm{CH}\right), 7.26\left(\mathrm{t}, 2 \mathrm{H}, J=7.5 \mathrm{~Hz}, 4^{\prime}-\mathrm{CH}\right), 7.39$ $\left(\mathrm{t}, 4 \mathrm{H}, J=7.5 \mathrm{~Hz}, 3^{\prime}, 5^{\prime}-\mathrm{CH}\right) .{ }^{13} \mathrm{C}$ NMR $(75 \mathrm{MHz}$, $\left.\mathrm{CDCl}_{3}\right): \delta=43.07\left(2 \mathrm{NCH}_{3}\right), 106.99(\mathrm{C}-3,6), 5.27$ $\left(2\left(\mathrm{C}-2^{\prime}, 6^{\prime}\right)\right), 6.18\left(2 \mathrm{C}-4^{\prime}\right), 9.43\left(2\left(\mathrm{C}-3^{\prime}, 5^{\prime}\right)\right), 147.89$ (2(C-1')), 151.32 (C-2,5), 181.68 (C-1,4).

2-(2-Methoxyphenylamino)cyclohexa-2,5dieno-1,4-dione (2c). Dark brown crystals, 
m. p. $107-114^{\circ} \mathrm{C}$ (lit. m. p. $114^{\circ} \mathrm{C}[6]$ ). ${ }^{1} \mathrm{H}$ NMR $\left(300 \mathrm{MHz}, \mathrm{DMSO}-\mathrm{d}_{6}\right): \delta=3.83\left(\mathrm{~s}, 3 \mathrm{H}, 2^{\prime}-\mathrm{OCH}_{3}\right)$, 5.57 (br. s., $0.7 \mathrm{H}, 3-\mathrm{CH}$ ), 6.56 (br. s., $0.3 \mathrm{H}, 3-\mathrm{CH}$ ), 6.70 ((br. d., $J=9.9 \mathrm{~Hz}, 1 \mathrm{H}, 5-\mathrm{CH}), 6.82$ (br. d., $J=10.1 \mathrm{~Hz}, 1 \mathrm{H}, 6-\mathrm{CH}$ ), 6.99-7.32 (br. m., $4 \mathrm{H}$, $3^{\prime}, 4^{\prime}, 5^{\prime}, 6^{\prime}-\mathrm{CH}$ ), 8.35 (br. s., $0.8 \mathrm{H}, \mathrm{NH}$ ), 8.61 (br. s., $0.2 \mathrm{H}, \mathrm{NH}) .{ }^{13} \mathrm{C}$ NMR $(75 \mathrm{MHz}, \mathrm{DMSO}-$ $\left.\mathrm{d}_{6}\right): \delta=55.72\left(\mathrm{OCH}_{3}\right), 100.08(\mathrm{C}-3), 1.05\left(\mathrm{C}-3^{\prime}\right)$, 0.80 (C-5'), $3.75\left(\mathrm{C}-6^{\prime}\right), 6.07$ (C-1'), 6.68 (C-42), 132.92 (C-5), 139.11 (C-6), 143.70 (C-2), 152.09 (C-2'), 183.60 (C-4), 185.66 (C-1).

2-(4-Methoxyphenylamino)cyclohexa-2,5dieno-1,4-dione (2d). Dark violet crystals, m. p. $121-129^{\circ} \mathrm{C}$ (lit. m. p. $132-134^{\circ} \mathrm{C}$ [9], lit. m. p. $\left.\left.155-156^{\circ} \mathrm{C}[8]\right)\right) .{ }^{1} \mathrm{H}$ NMR (300 $\mathrm{MHz}, \mathrm{CDCl}_{3}$ ): $\delta=3.81$ (s, $\left.3 \mathrm{H}, 4^{\prime}-\mathrm{OCH}_{3}\right), 5.98$ (br. s., $1 \mathrm{H}, 3-\mathrm{CH}$ ), 6.68 (br. s., $2 \mathrm{H}, 5,6-\mathrm{CH}$ ), 6.91 (br. m., $2 \mathrm{H}, 2^{\prime}, 6^{\prime}-$ $\mathrm{CH}$ ), 7.13 (br. m., 2H, 3',5'-CH + NH).

2-(2-Fluorophenylamino)cyclohexa-2,5-dieno-1,4-dione, 2,5-bis(2- fluorophenylamino) cyclohexa-2,5-dieno-1,4-dione and 2,5-bis(2fluorophenylamino)-4-(2-fluorophenylimino) cyclohexa-2,5-dien-1-one (2e, 3e, 4e). After filtration, the obtained product mixture was purified by dry column chromatography in the eluent system benzene-dichloroethane with a gradient from 10:0 to $0: 10$. The collected three fractions were subsequently concentrated under reduced pressure, the solid residues were filtered by using diethyl ether to give mono substituted $2 \mathrm{e}\left(\mathrm{R}_{\mathrm{f}} 0.32\right)$, disubstituted 3e $\left(\mathrm{R}_{\mathrm{f}} 0.45\right)$ and trisubstituted $4 \mathbf{e}$ $\left(R_{f} 0.57\right)$ derivatives, yield 43,18 and $15 \%$, respectively.

2-(2-Fluorophenylamino)cyclohexa-2,5dieno-1,4-dione (2e). Dark red crystals, m. p. $118-122^{\circ} \mathrm{C}$. Anal. calcd. for $\mathrm{C}_{12} \mathrm{H}_{8} \mathrm{FNO}_{2}(217.2)$ : C 66.36; H 3.71; N 6.45. Found: C 66.47; H 3.59; $\mathrm{N}$ 6.61. ${ }^{1} \mathrm{H}$ NMR $\left(300 \mathrm{MHz}, \mathrm{DMSO}-\mathrm{d}_{6}\right): \delta=5.30$ (br. m., $1 \mathrm{H}, 3-\mathrm{CH}), 6.71(\mathrm{dd}, J=2.1 \mathrm{~Hz}, J=10.0 \mathrm{~Hz}$, $1 \mathrm{H}, 5-\mathrm{CH}), 6.82(\mathrm{~d}, J=10.0 \mathrm{~Hz}, 1 \mathrm{H}, 6-\mathrm{CH}), 7.24-$ 7.45 (m, 4H, 3', 4', 5', 6'-CH), 8.90 (br. s., $1 \mathrm{H}, \mathrm{NH}$ ). ${ }^{13} \mathrm{C}$ NMR $\left(75 \mathrm{MHz}, \mathrm{DMSO}-\mathrm{d}_{6}\right): \delta=100.45(\mathrm{C}-3)$, $116.55\left({ }^{2} J_{\mathrm{CF}}=19.2 \mathrm{~Hz}, \mathrm{C}-3{ }^{\prime}\right), 125.03\left({ }^{2} J_{\mathrm{CF}}=12.8 \mathrm{~Hz}\right.$, C-1'), $127.57\left(\mathrm{C}-5^{\prime}\right), 128.20\left({ }^{3} J_{\mathrm{CF}}=7.8 \mathrm{~Hz}, \mathrm{C}-4^{\prime}\right)$, 133.16 (C-5), 138.77 (C-6), 145.02 (C-2), 156.01 $\left({ }^{1} J_{\mathrm{CF}}=249.0 \mathrm{~Hz}, \mathrm{C}-2^{\prime}\right), 183.36(\mathrm{C}-4), 185.77(\mathrm{C}-1)$. ${ }^{19} \mathrm{~F}$ NMR $\left(282 \mathrm{MHz}\right.$, DMSO-d $\left.{ }_{6}\right): \delta=-66.92(\mathrm{~s}, 1 \mathrm{~F}$, $\left.2^{\prime}-\mathrm{F}\right)$.

2,5 -bis ( 2 - Fluorophenylam ino) cyclohexa-2,5-dieno-1,4-dione (3e). Dark brown crystals, m. p. $190-200^{\circ} \mathrm{C}$. Anal. calcd. for $\mathrm{C}_{18} \mathrm{H}_{12} \mathrm{~F}_{2} \mathrm{~N}_{2} \mathrm{O}_{2}$ (326.30): C 66.26; $\mathrm{H}$ 3.71; $\mathrm{N} 8.59$. Found: $\mathrm{C} 66.40 ; \mathrm{H}$ 3.59; $\mathrm{N}$ 8.73. ${ }^{1} \mathrm{H}$ NMR $\left(400 \mathrm{MHz}, \mathrm{DMSO}-\mathrm{d}_{6}\right): \delta=5.24$ (br. d., $J=1.7 \mathrm{~Hz}$, $2 \mathrm{H}, \quad 3,5-\mathrm{CH}), \quad 7.25-7.45\left(\mathrm{~m}, \quad 8 \mathrm{H}, 3^{\prime}, 4^{\prime}, 5^{\prime}, 6^{\prime}-\right.$ $\mathrm{CH}), 9.23$ (br. s., $2 \mathrm{H}, \mathrm{NH}) .{ }^{13} \mathrm{C}$ NMR $(75 \mathrm{MHz}$, DMSO-d $\left.{ }_{6}\right): \quad \delta=95.92 \quad(\mathrm{C}-3,6), \quad 116.54$ $\left({ }^{2} J_{\mathrm{CF}}=19.3 \mathrm{~Hz}, 2 \mathrm{C}-3^{\prime}\right), 125.02\left({ }^{2} J_{\mathrm{CF}}=12.0 \mathrm{~Hz}\right.$, $\left.2 \mathrm{C}-1^{\prime}\right), 125.14\left({ }^{3} J_{\mathrm{CF}}=3.7 \mathrm{~Hz}, \mathrm{C}-6^{\prime}\right), 127.64\left(\mathrm{C}-5^{\prime}\right)$, $128.56\left({ }^{3} J_{\mathrm{CF}}=7.8 \mathrm{~Hz}, \mathrm{C}-4^{\prime}\right), 148.22(\mathrm{C}-2), 156.00$ $\left({ }^{1} J_{\mathrm{CF}}=249.1 \mathrm{~Hz}, \mathrm{C}-2^{\prime}\right), 179.34(\mathrm{C}-1,4) .{ }^{19} \mathrm{~F} \mathrm{NMR}$ $\left(282 \mathrm{MHz}, \mathrm{DMSO}_{\mathrm{d}}\right): \delta=-67.54\left(\mathrm{~s}, 1 \mathrm{~F}, 2^{\prime}-\mathrm{F}\right)$.

2,5-bis(2-Fluorophenylamino)-4-(2-fluorophenylimino)cyclohexa-2,5-dien-1-one (4e). Dark red crystals, m. p. $124-127^{\circ} \mathrm{C}$. Anal. calcd. for $\mathrm{C}_{24} \mathrm{H}_{16} \mathrm{~F}_{3} \mathrm{~N}_{3} \mathrm{O}$ (419.40): C 68.73; $\mathrm{H}$ 3.85; N 10.02. Found: C 68.51; H 3.71; N 10.16. ${ }^{1} \mathrm{H}$ NMR $\left(400 \mathrm{MHz}, \mathrm{CDCl}_{3}\right.$ ): 5.98 (br. d., $J=2.0 \mathrm{~Hz}, 1 \mathrm{H}$, 3-CH), $6.06(\mathrm{~d}, J=0.8 \mathrm{~Hz}, 1 \mathrm{H}, 6-\mathrm{CH}), 7.00-7.23$ $\left(\mathrm{m}, 11 \mathrm{H}, \mathrm{CH}_{\mathrm{ar}}\right), 7.48-7.53\left(\mathrm{~m}, 1 \mathrm{H}, 6^{\prime}-\mathrm{CH}\right), 7.70$ (s, $1 \mathrm{H}, \mathrm{NH}), 8.70(\mathrm{~s}, 1 \mathrm{H}, \mathrm{NH}) .{ }^{13} \mathrm{C}$ NMR $(100 \mathrm{MHz}$, $\left.\mathrm{CDCl}_{3}\right): \delta=91.67(6-\mathrm{CH}), 98.03(3-\mathrm{CH}), 116.14$ $\left(d,{ }^{2} J_{C F}=19.8 \mathrm{~Hz}, 3^{\prime}-\mathrm{CH}\right), 116.16\left(\mathrm{~d},{ }^{2} J_{\mathrm{CF}}=19.4 \mathrm{~Hz}\right.$, $\left.3^{\prime}-\mathrm{CH}\right), 116.38\left(\mathrm{~d},{ }^{2} J_{\mathrm{CF}}=19.5 \mathrm{~Hz}, 3^{\prime}-\mathrm{CH}\right), 121.68$ $\left(5^{\prime}-\mathrm{CH}\right), 123.21\left(5^{\prime}-\mathrm{CH}\right), 124.31\left(5^{\prime}-\mathrm{CH}\right), 124.31$ $\left(d,{ }^{3} J_{C F}=4.6 \mathrm{~Hz}, 6^{\prime}-C H\right), 124.38\left(\mathrm{~d},{ }^{3} J_{\mathrm{CF}}=4.0 \mathrm{~Hz}\right.$, $\left.6^{\prime}-\mathrm{CH}\right), 124.63\left(\mathrm{~d},{ }^{3} J_{\mathrm{CF}}=4.0 \mathrm{~Hz}, 6^{\prime}-\mathrm{CH}\right), 125.12$ $\left(\mathrm{d},{ }^{3} J_{\mathrm{CF}}=7.5 \mathrm{~Hz}, 4^{\prime}-\mathrm{CH}\right), 126.23\left(d,{ }^{3} J_{C F}=7.4 \mathrm{~Hz}\right.$, $\left.4^{\prime}-\mathrm{CH}\right), 126.54\left(\mathrm{~d},{ }^{3} J_{\mathrm{CF}}=7.5 \mathrm{~Hz}, 4^{\prime}-\mathrm{CH}\right), 126.00(\mathrm{~d}$, $\left.{ }^{2} J_{\mathrm{CF}}=11.6 \mathrm{~Hz}, 1^{\prime}-\mathrm{CH}\right), 126.59\left(\mathrm{~d},{ }^{2} J_{\mathrm{CF}}=11.5 \mathrm{~Hz}\right.$, $\left.1^{\prime}-\mathrm{CH}\right), 136.33\left(d,{ }^{2} J_{C F}=11.7 \mathrm{~Hz}, 1^{\prime}-\mathrm{CH}\right), 140.73$ (2-CH), $148.77(5-\mathrm{CH}), 152.84\left(\mathrm{~d},{ }^{1} J_{\mathrm{CF}}=247.7 \mathrm{~Hz}\right.$, $\left.2^{\prime}-\mathrm{CH}\right), 154.74\left(\mathrm{~d},{ }^{1} J_{\mathrm{CF}}=247.8 \mathrm{~Hz}, 2^{\prime}-\mathrm{CH}\right), 155.25$ $(\mathrm{C}=\mathrm{N}), 155.67\left(d,{ }^{1} J_{C F}=248.6 \mathrm{~Hz}, 2^{\prime}-\mathrm{CH}\right), 180.58$ (CO). ${ }^{19} \mathrm{~F}$ NMR $\left(282 \mathrm{MHz}, \mathrm{CDCl}_{3}\right): \delta=-73.19$, $-73.36,-74.14$ (s, 3F, 2'-F). The spectral data of the third composed aromatic ring of compound $\mathbf{4 e}$ are marked in italic.

2-(4-Fluorophenylamino)cyclohexa-2,5-dieno-1,4-dione (2f). Brown-black crystals, m. p. $135-140^{\circ} \mathrm{C}$. Anal. calcd. for $\mathrm{C}_{12} \mathrm{H}_{8} \mathrm{FNO}_{2}$ (217.2): C 66.36; H 3.71; N 6.45. Found: C 66.19; H 3.60; $\mathrm{N}$ 6.62. ${ }^{1} \mathrm{H}$ NMR $\left(300 \mathrm{MHz}, \mathrm{CDCl}_{3}\right): \delta=6.00$ (d, $J=1.7 \mathrm{~Hz}, 1 \mathrm{H}, 3-\mathrm{CH}$ ), 6.73 (br. m., 2H, 5,6$\mathrm{CH}$ ), 7.08-7.20 (br. m., 4H, 2', 3', $5^{\prime}, 6^{\prime}-\mathrm{CH}+1 \mathrm{H}$, $\mathrm{NH}) .{ }^{13} \mathrm{C}$ NMR $\left(75 \mathrm{MHz}, \mathrm{CDCl}_{3}\right): \delta=100.61$ $(\mathrm{C}-3), 116.62\left({ }^{2} J_{\mathrm{CF}}=23.0 \mathrm{~Hz}, \mathrm{C}-3^{\prime}, 5^{\prime}\right), 124.68$ $\left({ }^{3} J_{\mathrm{CF}}=8.4 \mathrm{~Hz}, \mathrm{C}-2^{\prime}, 6^{\prime}\right), 132.39(\mathrm{C}-5), 133.05$ $\left({ }^{4} J_{\mathrm{CF}}=2.9 \mathrm{~Hz}, \mathrm{C}-1^{\prime}\right), 139.70(\mathrm{C}-6), 143.52(\mathrm{C}-2)$, $160.29\left({ }^{1} J_{\mathrm{CF}}=246.7 \mathrm{~Hz}, \mathrm{C}-4^{\prime}\right), 183.52(\mathrm{C}-4), 186.46$ 
(C-1). ${ }^{19} \mathrm{~F}$ NMR $\left(282 \mathrm{MHz}, \mathrm{CDCl}_{3}\right): \delta=-68.15(\mathrm{~s}$, $\left.1 \mathrm{~F}, 4^{\prime}-\mathrm{F}\right)$.

\section{Computational background and methods/ calculations}

The DFT calculations were performed with the B3LYP and $6-311+\mathrm{g}(\mathrm{d}, \mathrm{p})$ basis set using the Gaussian 09 program package [23] for BQ and $\mathbf{2 a}-\mathbf{f}, \mathbf{3 b}$ of quinones $(\mathrm{Q})$ and hydroquinones $\left(\mathrm{QH}_{2}\right)(+2 \mathrm{e}-$ and $+2 \mathrm{H}+)$. The use of the B3LYP hybrid functional at the DFT level is the most popular choice for treatment of heteroaromatic derivatives which matches well with the experimental observations [24-27]. The use of 6-311G, 6-31G basis sets accomplished with additional diffuse and polarized functions for the aromatic heterocycles also provided comparable results [28-31]. In this investigation, the search of a reasonable basis set has been explored for BQ and compounds $\mathbf{2} \mathbf{a}-\mathbf{f}, \mathbf{3} \mathbf{b}$. Thus, the electronic parameters and the optimal geometries of compound $\mathbf{2 a}$ in the form of $\mathrm{Q}$ and $\mathrm{QH}_{2}$ have been calculated by means of $6-311+g(d, p)$ and $6-311++g(d, p)$ basis sets. The calculated values of the electronic parameters revealed negligible differences for both basis sets. Therefore, we chose the $6-311+g(d, p)$ basis set for the other BQ and $\mathbf{2 a - f}, \mathbf{3} \mathbf{b}$ calculations. Ionic structures having neutral molecule geometry were also calculated to obtain vertical ionization energies and electron affinities. Initial structures were modelled and prepared for calculation with GaussView 5 [32]. The following electronic parameters were calculated and analysed: vertical ionization energy $I_{v}$ - energy needed to remove one electron from a neutral molecule without changing its geometry (measure of electron donating power)

$$
I_{v}=E\left(M_{n}^{+1}\right)-E\left(M_{n}^{0}\right)
$$

vertical electron affinity $A_{v}$ - gain (or loss if negative) of energy after one electron addition to a molecule (electron accepting power)

$$
A_{v}=E\left(M_{n}^{0}\right)-E\left(M_{n}^{-1}\right)
$$

chemical potential $\mu_{v}$ (negative electronegativity $x[33])$

$$
\mu_{v}=\frac{\partial E}{\partial N}=-\chi \approx-\left(I_{v}+A_{v}\right) / 2
$$

chemical hardness $\eta_{v}$ (resistance to the change number of electrons in a molecule [33-35])

$$
\eta_{v}=\frac{\partial^{2} E}{\partial N^{2}} \approx I_{v}-A_{v}
$$

the fractional number of electrons to be added to the molecule to get its minimal energy without changing the geometry $\Delta N_{\max }$ :

$$
\Delta N_{\max }=-\mu / \eta
$$

Here $E\left(M_{n}^{+1}\right)$ stands for the total energy of the molecule $M$ being a cation (net charge equal to +1 ), and having neutral (subscript $n$ ) molecule geometry, $N$ is the number of electrons in the molecule. Energy of HOMO-LUMO gap $\left(\Delta E_{\mathrm{H}-\mathrm{L}}\right)$ was calculated from the differences of LUMO and HOMO energies of neutral Q or $\mathrm{QH}_{2}$

$$
\Delta E_{\mathrm{H}-\mathrm{L}}=E_{\mathrm{LUMO}}-E_{\text {НОМО }}=\eta_{K} \text {, }
$$

and it is equal to the hardness calculated using the Koopman's theorem [36, 37].

The concepts of chemical potential $\mu_{v}$ and chemical hardness $\eta_{v}$ arise from the Taylor series expansion of molecule energy dependence on the electron number $E=E(\mathrm{~N})$ when geometry is fixed and leaving only first two series terms

$$
\Delta E=\mu_{v}(\Delta N)+\frac{1}{2} \eta_{v}(\Delta N)^{2},
$$

where according to formulas (3) and (4) the first order derivative (slope) is $\mu_{v}$ and the second one (curvature) is $\eta_{v}$.

\section{RESULTS AND DISCUSSION}

\section{Chemistry}

A synthesis of the studied 2-arilamino substituted 1,4-benzoquinone derivatives is presented in the Scheme.

Target 2-substituted compounds $\mathbf{2 a - f}$ were obtained by the reaction of $\mathrm{BQ}$ with the corresponding aromatic amine 1a-f in an aqueous acetic acid solution. The first attempt to synthesise 2-substituted derivatives $\mathbf{2} \mathbf{c}$, $\mathbf{d}$ by the treatment of BQ with $o$ - and $p$ - - methoxyanilines $(\mathbf{1} \mathbf{c}, \mathbf{d})$ at the described conditions [6] was unsuccessful, we did not succeed to separate and purify purposive compounds. The main reasons for this failure were the 


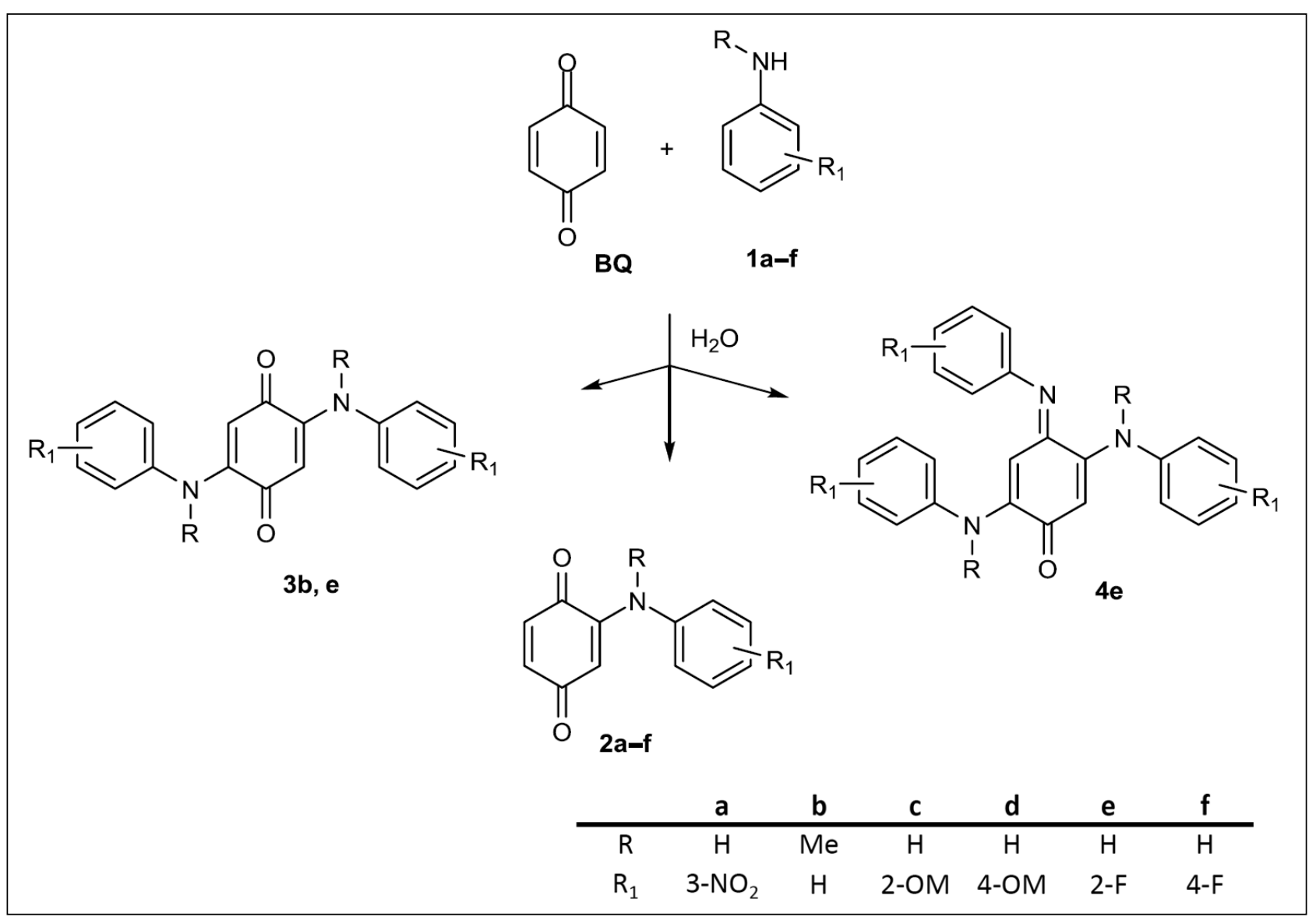

Scheme. The general scheme of the synthesis of 1,4-benzoquinone derivatives $2 a-f, 3 b$, e and $4 e$

formation of the considerable amount of 2,5-disubstituted products in these reaction conditions. With the aim to minimise its amount, the reaction temperature, time, dilution and ratio of reacting components were varied to optimise the synthesis conditions of the target 2-arylamino-1,4-benzoquinones $\mathbf{2 a - f}$ and 3b. The results of this investigation are presented in Table 1 .

The yield of compounds $2 \mathbf{a}-\mathbf{f}$ and $\mathbf{3 b}$ was moderate because the reaction process was stopped at the start of formation of the first crystals. If the re- action mixture is kept till the end of crystallisation, the mixtures of several products are always obtained. Product purification and isolation from the mixture is complicated.

Since $m$-nitro-, $o$ - and $p$-methoxyanilino-1,4benzoquinones $\mathbf{2 a}, \mathbf{c}, \mathbf{d}$ were described previously $[6,8,9,21]$, we focused on the investigation of interactions of $o$ - and $p$-fluoroaniline $(\mathbf{1 e}$, f) with $\mathrm{BQ}$. It was established that the reaction of $o$-fluoroaniline with quinone even at $0^{\circ} \mathrm{C}$ temperature and the high dilution gave the mixture

Table 1. Optimal synthesis conditions for 2 - and 2,5-arylamino- 1,4-benzoquinone derivatives $2 a-f$ and $3 b$

\begin{tabular}{c|c|c|c|c|c}
\hline Compound & $\boldsymbol{t}, \mathbf{m i n}$ & $\mathbf{T},{ }^{\circ} \mathbf{C}$ & BQ/amine, $\mathbf{~ m o l} / \mathbf{m m o l}$ & $\mathbf{B Q} / \mathbf{H}_{\mathbf{2}} \mathbf{O}, \mathbf{~ m m o l} \mathbf{~ m l}$ & Yield, \% \\
\hline $\mathbf{2 a}$ & 20 & 60 & $1: 1$ & $20 / 40$ & 61 \\
\hline $\mathbf{2 b}$ & 15 & 5 & $2: 1$ & $20 / 200$ & 43 \\
\hline $\mathbf{3 b}$ & 20 & 60 & $1: 1$ & $20 / 40$ & 54 \\
\hline $\mathbf{2 c}$ & 15 & 5 & $2: 1$ & $20 / 200$ & 54 \\
\hline $\mathbf{2 d}$ & 15 & 5 & $2: 1$ & $20 / 200$ & 48 \\
\hline $\mathbf{2 e}$ & 15 & 0 & $2: 1$ & $20 / 300$ & 43 \\
\hline $\mathbf{2 f}$ & 15 & 5 & $2: 1$ & $20 / 200$ & 37 \\
\hline
\end{tabular}


of three products - mono-, di- and trisubstituted benzoquinone derivatives $\mathbf{2 e}, \mathbf{3 e}$ and $\mathbf{4 e}$, yield 43 , 18 and $15 \%$, respectively. The formation of the trisubstituted derivative was unexpected, since some authors accent that the carbonyl group of benzoquinone does not react with aromatic amines under these conditions [阬. It should be noted that in the case when $o$-fluoroaniline le was used, we did not succeed to establish the correct version of the reaction conditions leading to one product - monosubstituted derivative 2e. Compound $2 \mathbf{e}$ was isolated from the mixture by column chromatography. Meanwhile, in the reaction with $p$-fluoroaniline $\mathbf{1 f}$, only one compound $\mathbf{2 f}$ was isolated.

In addition, it is imperative to note that the melting point of some synthesised compounds does not correspond to the literature data (see Experimental). The main reason for this may be a dark intense colour of the synthesised compounds, which becomes completely black during the melting decomposition of the material. The melting range of these dark products is difficult to determine. Consequently, the structure of the synthesised compounds was investigated in detail by NMR spectroscopy.

The structure of all newly synthesised 1,4-benzoquinone derivatives was identified by the ${ }^{1} \mathrm{H}$, ${ }^{13} \mathrm{C},{ }^{1} \mathrm{H} /{ }^{13} \mathrm{C}$ 2D (HETCOR and HMBC) NMR spectra [38]. The resonances were assigned on the basis of arguments of chemical shift theory, signal intensity, and by the consideration of spinspin coupling multiplets. The title compounds are formed of 1,4-benzoquinone and substituted aniline moieties, and observed by characteristic patterns in the NMR spectra. 2-Monosubstituted 1,4-quinones $\mathbf{2 a}-\mathbf{f}$ are presented by the proper spin-spin $A B X$ multiplet, determined by the interaction of 3, 5 and 6 hydrogens in the ${ }^{1} \mathrm{H}$ NMR spectra, and by 6 separate resonances in the ${ }^{13} \mathrm{C}$ NMR spectra. In the case of 2,5-substitution, 1,4-benzoquinones $\mathbf{3} \mathbf{b}, \mathbf{3 e}$ alone resonance of hydrogens 3, 6 and three resonances of C-1/C-4, C-2/C-5, C-3/C6 were detected in ${ }^{1} \mathrm{H}$ and ${ }^{13} \mathrm{C}$ NMR, respectively.

The studied compounds $\mathbf{2 e}, \mathbf{f}$ and $3 \mathbf{e}, \mathbf{4 e}$ possess a fluorine atom at the $o$ - or $p$-position of the aromatic ring. Due to the specific magnetic properties of the fluorine atom, spin-spin coupling (up to 4 bonds) multiplets were observed in the ${ }^{1} \mathrm{H}$ and ${ }^{13} \mathrm{C}$ NMR spectra [39]. The splitting, arising from the fluorine, complicates the analysis of the aromatic region of the NMR spectra. The multiplets of the aromatic resonances in the ${ }^{1} \mathrm{H}$ NMR spectra overlap and are insufficiently informative, whereas in the case of the ${ }^{13} \mathrm{C}$ NMR spectra the multiplets are resolved. The difference of ${ }^{2} J_{\mathrm{CF}}{ }^{3} J_{\mathrm{CF}}$ values observed in the ${ }^{13} \mathrm{C}$ NMR spectra for the same aromatic ring can be rationalised in terms of the substituent effects [40, 41]. Taking into account the investigated compounds $4 \mathbf{e}$ bearing $3 o$-fluorine substituted aromatic rings, 3 sets of the corresponding aromatic ring chemical shifts and $J$ values were observed in the ${ }^{13} \mathrm{C}$ NMR spectra. The formation of compounds $4 \mathbf{e}$ was proved by the presence of resonance at about $155 \mathrm{ppm}(\mathrm{C}=\mathrm{N})$ and $180 \mathrm{ppm}(\mathrm{C}=\mathrm{O})$ and 3 signals in the ${ }^{19} \mathrm{~F}$ resonance spectrum integrated to one fluorine atom. Two signals of fluorine are broadened and one is sharp due to a different interconnection between benzoquinone and aromatic moieties. The spectral data of the third aromatic ring in compound $\mathbf{4 e}$ are marked in italic, to indicate the dissimilarity of other two aromatic rings.

The presence and location of substituents of the aniline moiety were proved by the analysis of NMR data and ascertaining a characteristic influence on the chemical shifts and spin-spin coupling constants of study compounds.

The obtained NMR data are listed in the Experimental section.

\section{Theoretical studies}

The title study has been further extended aiming to indicate the possible oxidative (for dihydro-1,4benzoquinones) and reductive (for 1,4-benzoquinones) ability of the newly synthesised arylamino-1,4-benzoquinones $\mathbf{2} \mathbf{a}-\mathbf{f}, \mathbf{3} \mathbf{b}$ by means of calculation appropriate QSAR descriptors. Aiming to select the most promising redox mediator candidates the obtained computational results have been compared with those of the well-known standard mediator 1,4-benzoquinone (BQ).

The electrochemical oxidation reaction of dihydro-1,4-benzoquinone derivatives $\left(\mathrm{QH}_{2}\right)$ proceeded with the two electron and two proton transfer yielding benzoquinones $(\mathrm{Q})$

$$
\mathrm{QH}_{2} \rightarrow \mathrm{Q}+2 \mathrm{e}^{-}+2 \mathrm{H}^{+},
$$


and the reversible reduction process $[42,43$,

$$
\mathrm{Q}+2 \mathrm{e}^{-}+2 \mathrm{H}^{+} \rightarrow \mathrm{QH}_{2}
$$

was broadly described in the past based on cyclic FT-IR spectroelectrochemistry and cyclic voltabsorptometry [4, 42-45]. In this context, it is important to find descriptors revealing the oxidative and reductive activity of $\mathbf{2 a - f}, \mathbf{3 b}$ in the forms of $\mathrm{QH}_{2}$ and $\mathrm{Q}$, respectively.

A lot of work has been done in the field of theoretical chemistry in the prediction of the reactivity and definition of molecular meaningful QSAR descriptors [15, 17, 46-50]. In particular, density functional theory (DFT) has provided formal definitions for many descriptors [33, 51] and a part of them have been used as a tool to study the electrochemical redox reaction [4, 52-54]. In the present work definitions presented in the Computational
Background Section like $\eta$, the energy gap $\Delta E_{\mathrm{H}-\mathrm{L}}$ between LUMO and HOMO, $I_{v}, A_{v}$, the HOMO energy $\left(E_{\mathrm{H}}\right)$ and $\Delta N_{\max }$ have been used to express the oxidative (for $\mathrm{QH}_{2}$ ) and reductive (for $\mathrm{Q}$ ) ability of arylamino-1,4-benzoquinones $\mathbf{2 a - f}, \mathbf{3 b}$ and BQ. The calculated quantum chemical indices are presented in Table 2 .

So, to find a theoretical relationship between $\mathrm{QH}_{2}$ structural and oxidative properties, the $E_{\mathrm{H}}$ and $I_{v}$ quantities have been considered. The ionisation potential means the amount of energy needed to remove an electron from an isolated gaseous atom or a molecule. So, it can be a meaningful measure of molecular oxidative ability. Another way to calculate the ionisation potential is the Koopman's theorem [36, 37]. According to it the ionisation potential is equal to the negative value of the energy of the HOMO orbital. Low ionization energy infers an easy removal of an

Table 2. QSAR descriptors of 2- and 2,5-arylamino- 1,4-benzoquinone derivatives $2 a-f, 3 b$ and benzoquinone (BQ). Calculated in the form of quinones $(\mathrm{Q})$ and hydroquinones $\left(\mathrm{QH}_{2}\right)$

\begin{tabular}{|c|c|c|c|c|c|c|c|}
\hline Compound & $I_{v}, \mathrm{eV}$ & $A_{v \prime}, \mathrm{eV}$ & $E_{\mathrm{H},} \mathrm{eV}$ & $\mu_{v \prime} \mathrm{eV}$ & $\eta_{v,} \mathrm{eV}$ & $\Delta N_{\text {max }}$ & $\Delta E_{\mathrm{H}-\mathrm{L},} \mathrm{eV}$ \\
\hline \multicolumn{8}{|l|}{$\mathrm{BQ}$} \\
\hline$Q$ & 9.972 & 1.895 & -7.809 & -5.933 & 8.077 & 0.735 & 3.859 \\
\hline $\mathrm{QH}_{2}$ & 7.972 & -1.207 & -5.885 & -3.383 & 9.180 & 0.368 & 5.196 \\
\hline \multicolumn{8}{|l|}{$2 a$} \\
\hline$Q$ & 8.409 & 2.184 & -6.808 & -5.424 & 5.971 & 0.908 & 2.936 \\
\hline $\mathrm{QH}_{2}$ & 7.283 & 0.831 & -5.714 & -4.057 & 6.452 & 0.629 & 3.018 \\
\hline \multicolumn{8}{|l|}{$2 b$} \\
\hline $\mathrm{Q}$ & 7.890 & 1.516 & -6.234 & -4.703 & 6.374 & 0.738 & 2.914 \\
\hline $\mathrm{QH}_{2}$ & 6.852 & -0.578 & -5.321 & -3.090 & 7.526 & 0.411 & 4.435 \\
\hline \multicolumn{8}{|l|}{$3 b$} \\
\hline Q & 7.187 & 1.084 & -5.712 & -4.098 & 6.178 & 0.663 & 3.152 \\
\hline $\mathrm{QH}_{2}$ & 6.407 & -0.323 & -5.138 & -3.042 & 6.730 & 0.452 & 4.155 \\
\hline \multicolumn{8}{|l|}{$2 c$} \\
\hline$Q$ & 7.579 & 1.704 & -6.011 & -4.641 & 5.875 & 0.790 & 2.571 \\
\hline $\mathrm{QH}_{2}$ & 6.586 & -0.654 & -5.064 & -2.966 & 7.241 & 0.410 & 4.435 \\
\hline \multicolumn{8}{|l|}{$2 d$} \\
\hline$Q$ & 7.562 & 1.699 & -6.00 & -4.631 & 5.862 & 0.790 & 2.536 \\
\hline $\mathrm{QH}_{2}$ & 6.597 & -0.625 & -5.073 & -2.986 & 7.222 & 0.413 & 4.553 \\
\hline \multicolumn{8}{|l|}{$2 e$} \\
\hline$Q$ & 8.074 & 1.892 & -6.445 & -4.983 & 6.181 & 0.806 & 2.783 \\
\hline $\mathrm{QH}_{2}$ & 6.972 & -0.506 & -5.397 & -3.233 & 7.478 & 0.432 & 4.526 \\
\hline \multicolumn{8}{|l|}{$2 f$} \\
\hline Q & 8.056 & 1.878 & -6.422 & -4.967 & 6.178 & 0.804 & 2.757 \\
\hline $\mathrm{QH}_{2}$ & 6.947 & -0.508 & -5.358 & -3.220 & 7.455 & 0.432 & 4.551 \\
\hline
\end{tabular}


electron and the molecule undergoes oxidation easily. As well, the $\mathrm{HOMO}$ energy of $\mathrm{QH}_{2}$ can also disclose the oxidative power of $\mathrm{QH}_{2}$. The higher HOMO energy the easier to remove electrons from the molecule.

The oxidative ability of the newly synthesised $\mathrm{QH}_{2}$ compounds $\mathbf{2 a}-\mathbf{f}, \mathbf{3 b}$ expressed as $I_{v}$ varied in a range from $6.41 \mathrm{eV}$ for $\mathbf{3 b}$ to $7.28 \mathrm{eV}$ for $\mathbf{2 a}$. The $E_{\mathrm{H}}$ varied from $-5.06 \mathrm{eV}$ for $2 \mathrm{c}$ to $-5.71 \mathrm{eV}$ for 2a. This evidently points that $\mathrm{QH}_{2} \mathbf{2 a}-\mathbf{f}, \mathbf{3 b}$ can act as electron transfer mediators and most of them can participate more efficiently in the oxidation process as compared to that of the standard $\mathrm{BQH}_{2}$ characterised by the higher $I_{v}$ of $7.97 \mathrm{eV}$ and the lower $E_{\mathrm{H}}$ value of $-5.89 \mathrm{eV}$. The electron donating ability revealing oxidation trends of $\mathrm{QH}_{2}$ calculated for $I_{v}$ decreases in the order $\mathrm{BQH}_{2}>\mathbf{2 a}>$ $\mathbf{2 e}>\mathbf{2 f}>\mathbf{2 b}>\mathbf{2 d}>\mathbf{2 c}>\mathbf{3 b}$, similar decreases in the order $\mathbf{2} \mathbf{c}>\mathbf{2 d}>\mathbf{3 b}>\mathbf{2} \mathbf{b}>\mathbf{2} \mathbf{a}>\mathrm{BQH}_{2}$ were obtained for HOMO's of $\mathrm{QH}_{2}$. So, the electron donating (oxidative) power of all $\mathrm{QH}_{2}$ compounds $\mathbf{2 a}-\mathbf{f}, \mathbf{3 b}$ is higher than that of $\mathrm{BQH}_{2}$. This phenomenon can be explained due to the presence of electron donating arylamino moieties, which are directly bonded to the quinone ring through the amino group.

Unlike the oxidative ability, the reductive ability of many mediators is sometimes weakly pronounced in the experiment, due to the difficulty to clearly express cathodic peaks. Despite the complexity of cathodic processes in an experiment, there are some theoretical QSAR descriptors used to estimate the electron accepting of mediators.

In our case the fractional number of electrons $\left(\Delta N_{\max }\right)$ clearly implies the electron accepting nature of mediators. This parameter characterises how many electrons should be added to a molecule to reach the minimum energy and testifies about the electron accepting ability of mediators.

The $\mathrm{Q}$ and $\mathrm{QH}_{2}$ of compound 2a have the highest possible saturation with electrons $\left(\Delta N_{\max }=0.908\right.$ and 0.629 for $\mathrm{Q}$ and $\mathrm{QH}_{2}$, respectively). $\Delta N_{\max }$ quantity for other compounds $\mathbf{2 b}-\mathbf{f}$ was somewhat smaller than for 2a. However, it is evident that the newly synthesised mediators $\mathbf{2 a}-\mathbf{f}$ express a higher ability to accept electrons than that of BQ $\left(\Delta N_{\max }=0.735\right.$ and 0.368 for $\mathrm{Q}$ and $\mathrm{QH}_{2}$, respectively).

The electron affinity $A_{v}$ is the meaningful measure for evaluation of electron accepting (reduc- tive) power. This characteristic means the energy lowering (or rising) after an electron addition to a neutral molecule. A high positive electron affinity value implies the molecule tends to accept an additional electron easily with the energy lowering while the negative value indicates molecule resistance to that (energetically unfavourable process).

As it was indicated above, all $\mathrm{QH}_{2}$ of $\mathbf{2 a - f}, \mathbf{3 b}$ exhibit an enhanced electron donating (oxidative) power due to the presence of the electron donating arylamino moiety as compared to BQ. Therefore, it was expected that the Q of $\mathbf{2 a}-\mathbf{f}, \mathbf{3} \mathbf{b}$ should be characterised by reduced electron accepting power with respect to BQ. However, $A_{v}$ and $\mu_{v}$ values which are responsible for the characterisation of electron accepting potency testify a more complicated picture. For example, the highest value of $A_{v}$ has the Q of $\mathbf{2 a}$ bearing a $3-\mathrm{NO}_{2}$ group bonded to the arylamino moiety as compared to other $\mathrm{Q}$ $\mathbf{2 b}-\mathbf{f}, \mathbf{3 b}$ and $\mathrm{BQ}$. The $\mathrm{NO}_{2}$ group is well known as an excellent electron acceptor characterised by negative inductive and mezomeric ( $-\mathrm{I}$ and $-\mathrm{M})$ effects. Meanwhile, compounds $\mathbf{2 e}$ and $\mathbf{2 f}$ substituted with a methoxy group $(+\mathrm{I},+\mathrm{M})$ and fluorine groups $(-\mathrm{I},+\mathrm{M})$ have $A_{v}$ values almost equal to that of BQ. Considering this, an expected result of the reduced electron accepting power was observed for $\mathrm{Q}$ of $\mathbf{2} \mathbf{b}$ and $\mathbf{3 b}$ compounds with the methyl group directly added to the $\mathrm{N}$ atom of the amine group. The calculation results in this case testify that the reduced electron addition power is possibly influenced by the electron donating methyl group $(+\mathrm{I})$. Also, it is worth mentioning the results that we have got for the electron accepting power of $\mathrm{QH}_{2}$. It is well known that hydroquinones are bad electron acceptors and this was shown by our calculations which provided negative values of $A_{v}$ for all $\mathrm{QH}_{2}$ except compound 2a. The $A_{v}$ value for 2a is positive and equal to $0.831 \mathrm{eV}$ showing that $\mathrm{QH}_{2}$ 2a can be a good electron acceptor.

Aiming to properly establish an insight into the electrochemical oxidation of hydroquinones and the reduction of quinones it is important to point out other definitions of molecular stability and reactivity. One of them is the absolute chemical hardness $\eta_{v}$ which reveals the power of a molecule both to accept and to remove electrons. The hardness measures the resistance of a chemical system to change in the number of electrons $[36,37]$. This means that $\eta_{v}$ can support 
the concept describing oxidative and reductive strengths of a mediator. The higher $\eta_{v}$ value corresponds to the higher resistance of the mediator to change in the number of electrons that means to be reduced or oxidised. The most accurate method to get hardness is formula (4), but there is another way to calculate $\eta_{i}$. In accordance to the Koopman's theorem [36, 37] and within the HF framework of molecular orbital theory, the absolute hardness can be calculated also as the energy gap between LUMO and HOMO orbitals. Thus, in this case the hardness corresponds to the gap between the HOMO and LUMO orbitals. The larger the HOMO-LUMO energy gap the harder, more resistant the mediator is. Even more, the hardness correlates quite well with the chemical reactivity of the molecule [16]. Thereby, this quantity can predict the effectiveness of the mediated system in the reaction process, that is the acception and donation of electrons.

The calculated hardness of all hydroquinones $\mathrm{QH}_{2} \mathbf{2 a}-\mathbf{f}$ and $\mathbf{3 b}$ was found to be gradually decreasing in the order of $\mathrm{BQH}_{2}>\mathbf{2 b}>\mathbf{2 e}>\mathbf{2} \mathbf{f}>\mathbf{2} \mathbf{c}>$ $\mathbf{2 d}>\mathbf{3 b}>\mathbf{2 a}$. Similarly, the hardness of Q 2a-f and $\mathbf{3 b}$ is gradually lowering in the order $\mathrm{BQ}>$ $\mathbf{2 b}>\mathbf{2 e}>\mathbf{2 f}>\mathbf{3 b}>\mathbf{2 a}>\mathbf{2 c}>\mathbf{2 d}$, which testifies the increased reductive or oxidative ability of $\mathbf{2 a}-\mathbf{f}$ and $\mathbf{3 b}$ as compared to $\mathrm{BQ}$ or $\mathrm{BQH}_{2}$, respectively. Compound $\mathbf{2 a}$ is characterised by the highest reactivity to donate and accept electrons and the lowest $\eta_{v}$ values. $\mathrm{BQ}$ and $\mathrm{BQH}_{2}$ show the highest $\eta_{v}$ values and the highest resistance to participate in redox reactions than that of new $\mathbf{2 a}-\mathbf{f}, \mathbf{3} \mathbf{b}$ hydroquinones and quinones. It indicates that $\mathbf{2 a - f}$ and $\mathbf{3 b}$ can more easily participate in redox reactions the than $\mathrm{BQ}$ and $\mathrm{BQH}_{2}$. The results of the HOMO-LUMO energy gap calculation presented in Table 2 confirm the redox regularities obtained by the analysis of $\eta_{v}$ values.

\section{CONCLUSIONS}

In summary, we have presented the synthesis study of a conjugate addition of aromatic amines: $\mathrm{N}$-methylaniline, $o^{-}, \mathrm{m}$ - and $p$-nitro-, methoxyand fluorosubstituted anilines to 1,4-benzoquinone. A series of new generation electron transfer mediators 2-arylaminosubstituted 1,4-benzoquinone derivatives with various substituents in the $o_{-}^{-}$, $m$ - and $p$-positions of the aromatic ring have been synthesised and optimal reaction conditions for the synthesis of each of them have been established.

The oxidative and reductive properties of the newly synthesised 2-arylamino-1,4-benzoquinones expressed by QSAR descriptors evidently point to that they can act as electron transfer mediators. The electron donating (oxidative) power of all arylamino-substituted 1,4-dihydrobenzoquinones is higher than that of 1,4-dihydrobenzoquinone. However, the calculated electron affinity testifies that the electron accepting potency of arylaminosubstituted 1,4-benzoquinone correlates well with the ability of substitutes to withdraw or donate electrons. Moreover, most of them should enhance the redox process as compared to the known standard 1,4-benzoquinone mediator. The experimental validation of these findings is the subject of our further work.

\section{ACKNOWLEDGEMENTS}

Computations were performed on resources at the High Performance Computing Center 'HPC Sauletekis' of the Vilnius University Faculty of Physics.

Received 28 February 2019 Accepted 15 March 2019

\section{References}

1. J. Castillo, S. Gáspár, S. Leth, et al., Sens. Actuators, $B$, 102(2), 179 (2004).

2. L. Carollo, A. Curulli, B. Floris, Appl. Organomet. Chem., 17(8), 589 (2003).

3. A. Chaubey, B. D. Malhotra, Biosens. Bioelectron., 17(6-7), 441 (2002).

4. C. Nagaraja, T. V. Venkatesha, Electrochim. Acta, 260, 221 (2018).

5. J. Razumiene, E. Cirbaite, V. Razumas, V. Laurinavicius, Sens. Actuators, B, 207(PB), 1019 (2015).

6. H. Suida, W. Suida, Justus Liebigs Ann. Chem., 416(2-3), 113 (1918).

7. M. Z. Barakat, S. K. Shehab, M. M. El-Sadr, J. Chem. Soc., 901 (1958).

8. A. N. Grinev, V. I. Shvedov, E. K. Panisheva, N. S. Bogdanova, I. S. Nikolaeva, G. N. Pershin, Pharm. Chem. J., 5(5), 247 (1971).

9. J. S. Yadav, B. V. S. Reddy, T. Swamy, K. S. Shankar, Monatsh. Chem., 139(11), 1317 (2008).

10. A. A. Yassin, Makromol. Chem., 176(9), 2571 (1975).

11. N. Makarova, A. Y. Berlin, Zh. Obshch. Khim., 37(3), 637 (1967). 
12. S. Berhe, A. Slupe, C. Luster, et al., Biorg. Med. Chem., 18(1), 134 (2010).

13. E. Eroğlu, H. Türkmen, S. Güler, S. Palaz, O. Oltulu, Int. J. Mol. Sci., 8(2), 145 (2007).

14. A. Oluwaseye, A. Uzairu, G. A. Shallangwa, S. E. Abechi, J. King Saud. Univ. Sci. (2018). DOI: 10.1016/j.jksus.2018.03.022.

15. A. Vektariene, J. Phys. Chem. A, 117(35), 8449 (2013).

16. A. Vektariene, G. Vektaris, J. Svoboda, ARKIVOC, (7), 311 (2009).

17. M. Karelson, V. S. Lobanov, A. R. Katritzky, Chem. Rev., 96(3), 1027 (1996).

18. R. A. Miranda-Quintana, M. Martínez González, P. W. Ayers, PCCP, 18(32), 22235 (2016).

19. U. Orozco-Valencia, J. L. Gázquez, A. Vela, J. Mol. Model., 24(9), (2018).

20. V. Reenu, J. Mol. Graph. Model., 61, 89 (2015).

21. G. Meyer, H. Suida, Justus Liebigs Ann. Chem., 416(2-3), 181 (1918).

22. M. F. Ansell, B. W. Nash, D. A. Wilson, J. Chem. Soc., 1963, 3012 (1963).

23. M. J. Frisch, G. W. Trucks, H. B. Schlegel, et al., Gaussian 09, Gaussian, Inc., Wallingford, CT, USA (2009).

24. C. A. Morgado, J. P. McNamara, I. H. Hillier, N. A. Burton, M. A. Vincent, J. Chem. Theory Comput., 3(5), 1656 (2007).

25. A. Vektariene, J. Phys. Org. Chem., 29(1), 21 (2016).

26. A. Vektariene, Lith. J. Phys., 58(3), 232 (2018).

27. A. Vektarienè, ChemistrySelect, 3(38), 10750 (2018).

28. S. J. Choe, Bull. Korean Chem. Soc., 33(9), 2861 (2012).

29. H. A. Carlson, T. B. Nguyen, M. Orozco, W. L. Jorgensen, J. Comput. Chem., 14(10), 1240 (1993).

30. R. Janciene, A. Vektariene, Z. Stumbreviciute, B. Puodziunaite, Monatsh. Chem., 142(6), 609 (2011).

31. R. Janciene, Z. Stumbreviciute, A. Vektariene, et al., J. Heterocycl. Chem., 46(6), 1339 (2009).

32. R. Dennington, T. Keith, J. Millam, GaussView, Version 5.0.9, Semichem, Inc., Shawnee Mission, KS, USA (2009).

33. P. K. Chattaraj, S. Giri, S. Duley, Chem. Rev., 111(2), PR43 (2011).
34. R. G. Pearson, J. Chem. Sci., 117(5), 369 (2005).

35. R. G. Pearson, Chemical Hardness: Application from Molecules to Solids, Wiley-VCH (1997).

36. T. Koopmans, Physica, 1(1-6), 104 (1934).

37. R. G. Parr, W. Yang, Density Functional Theory in Atoms and Molecules, Oxford University Press, New York (1989).

38. H. Friebolin, Basic One- and Two-dimensional NMR Spectroscopy. 5th Completely Revised and Updated Edition, 5th edn., Wiley-VCH, Weinheim (2010).

39. W. R. Dolbier Jr., Guide to Fluorine NMR for Organic Chemists, 2nd edn., John Wiley \& Sons, Inc. (2016).

40. H. Pizova, M. Havelkova, S. Stepankova, et al., Molecules, 22(11), (2017).

41. M. A. Ilies, D. Vullo, J. Pastorek, et al., J. Med. Chem., 46(11), 2187 (2003).

42. M. T. Huynh, C. W. Anson, A. C. Cavell, S. S. Stahl, S. Hammes-Schiffer, J. Am. Chem. Soc., 138(49), 15903 (2016).

43. J. J. Wang, H. Xie, B. K. Jin, Chinese J. Anal. Chem., 41(7), 1006 (2013).

44. Y. Lin, K. H. Wu, Q. Lu, et al., J. Am. Chem. Soc., 140(44), 14717 (2018).

45. P. S. Guin, S. Das, P. C. Mandal, Int. J. Electrochem., 2011, 22 (2011).

46. A. Vektariene, G. Vektaris, D. W. H. Rankin, Heteroat. Chem, 18(7), 695 (2007).

47. A. Vektariene, G. Vektaris, ARKIVOC, (16), 23 (2006).

48. A. Vektariene, G. Vektaris, Heteroat. Chem, 15(3), 263 (2004).

49. A. Vektarienè, G. Vektaris, Chemija, 29(3), 167 (2018).

50. R. Janciene, Z. Stumbreviciute, A. Vektariene, et al., Heteroat. Chem, 19(1), 72 (2008).

51. P. Geerlings, F. De Proft, W. Langenaeker, Chem. Rev., 103(5), 1793 (2003).

52. S. Munir, A. Shah, A. Rauf, et al., C. R. Chim., 16(12), 1140 (2013).

53. S. Munir, A. Shah, A. Rauf, et al., Electrochim. Acta, 88, 858 (2013).

54. A. H. Shah, A. Shah, U. A. Rana, et al., Electroanalysis, 26(10), 2292 (2014). 
Edita Voitechovič, Regina Jančienė, Gema Mikulskienė, Aušra Vektariené, Gytis Vektaris, Julija Razumienè

POTENCIALIŲ ELEKTRONŲ PERNAŠOS

MEDIATORIU巳 2-ARILAMINO-1,4-

BENZOCHINONO DARINIŲ SINTEZĖ IR

TEORINIS TYRIMAS

Santrauka

Medžiagos, pasižyminčios redokso savybemis ir gebančios reoksiduoti fermentus, yra kuriamos ir tiriamos jau kelis dešimtmečius. Chinoidinès struktūros junginiai yra vieni iš perspektyvių redokso savybėmis pasižyminčių mediatorių. 2-Arilamino-1,4-benzochinono dariniai, turintys du skirtingo aktyvumo deguonies atomus ir dèl to modifikuotas redokso savybes, palyginti su nepakeistu chinonu, yra potencialūs elektronu pernašos mediatoriai. Taip buvo ištirta 1,4-benzochinono ir aromatinių aminų: $\mathrm{N}$-metilanilino, $o-, m$ - ir $p$-nitro, metoksi- ir fluorpakeistų anilinų sąveika ir sintezuota eilè 2-arilamino-1,4-benzochinonų, turinčių ivvairius pakaitus benzeno žiedo $o$-, $m$ - ir $p$-padètyse. Nustatytos optimalios kiekvieno anilino prisijungimo reakcijos sąlygos: reakcijos laikas, temperatūra, reagentų bei tirpiklio (vanduo) santykiai. Sintezuotų junginių struktūra buvo patvirtinta BMR spektroskopijos metodais. 2-Arilamino-1,4-benzochinono darinių oksidacinès ir redukcinès savybès iqvertintos remiantis apskaičiuotais kvantinès chemijos reaktingumo indeksais. Skaičiavimų rezultatai parodè, kad naujai sintezuoti 2-arilamino-1,4-benzochinonai turètų efektyviau spartinti oksidacinị redukcini procesą, lyginant su žinomu standartu - 1,4-benzochinonu. 